\title{
Keragaman Sifat Kualitatif pada Sapi Silangan PO dan Belgian Blue Menggunakan Analisis Komponen Utama
}

\author{
Jakaria ${ }^{*}$, Fuadi Zulfikri' ${ }^{1}$, Edwar ${ }^{3}$, Mokhamad Fakhrul Ulum ${ }^{2}$, Rudy Priyanto ${ }^{1}$ \\ ${ }^{1}$ Departemen Ilmu Produksi dan Teknologi Peternakan, Fakultas Peternakan, IPB University, \\ Jl. Agatis, Babakan, Kec. Dramaga, Bogor, Jawa Barat Indonesia 16680 \\ ${ }^{2}$ Departemen Klinik Reproduksi dan Patologi, Fakultas Kedokteran Hewan, IPB Univerity, \\ Jl. Agatis, Babakan, Kec. Dramaga, Bogor, Jawa Barat Indonesia 16680 \\ ${ }^{3}$ Balai Embrio Ternak (BET) Cipelang \\ Kel. Cipelang, Kec. Cijeruk, Bogor, Jawa Barat Indoneia 16004 \\ *Email korespondensi: jakaria_karman@yahoo.co.id
}

(Diterima: 12-09-2019; disetujui: 12-12-2019)

\begin{abstract}
ABSTRAK
Tujuan penelitian ini adalah mengetahui keragaman sifat kualitatif pada sapi Peranakan ongole (PO), belgian blue, dan silangan PO-belgian blue menggunakan analisis komponen utama. Total sampel sapi yang digunakan sebanyak 36 ekor terdiri atas sapi belgian blue 8 ekor ( 4 ekor jantan dan 4 ekor betina), sapi silangan PO-belgian blue 17 ekor (11 ekor jantan dan 6 ekor betina), dan sapi PO 11 ekor (semua betina). Keragaman sifat kualitatif yang diamati sebanyak 17 karakteristik yaitu warna tubuh polos (WTP), warna tubuh kombinasi (WTK), beranduk (MT), berpunuk (MP), bergelambir (MG), warna ujung ekor hitam (WUEH), warna ujung ekor putih (WUEH), warna bulu mata hitam (WBMH), warna bulu mata putih (WBMP), pusaran rambut dikepala (PRK), pusaran rambut dipunggung (PRP), pusaran rambut dibelakang (PRB), warna kuku hitam (WKH), warna kuku putih (WKP), perototan ganda (PG), warna moncong hitam (WMH) dan warna moncong putih (WMP). Data sifat kualitatif dianalisis secara deskriptif yaitu dengan menghitung nilai proporsi, sedangkan peubah penentu setiap bangsa dianalisis menggunakan metode analisis komponen utama (AKU) dengan Program Minitab versi 7. Hasil penelitian memperlihatkan bahwa karakteristik sifat kualitatif pada sapi $\mathrm{PO}$, belgian blue, dan sapi silangan PO-belgian blue memiliki keragaman tinggi. Sapi PO dan belgian blue dapat dibedakan secara jelas berdasarkan karakteristik sifat kualitatif, sedangkan sapi silangan PO-belgian blue memiliki cluster yang dekat dengan cluster sapi PO. Ditemukan karakter penciri untuk masing-masing bangsa sapi baik pada sapi PO, belgian blue, dan sapi silangan PO-belgian blue. Terdapat tiga karakter sifat kualitatif yang dimiliki pada setiap bangsa sapi yaitu peubah pusaran rambut dikepala (PRK), pusaran rambut dipunggung (PRP) dan karakter bertanduk (MT). Berdasarkan hasil yang diperoleh bahwa karakter sifat kualitatif pada sapi dapat dijadikan sebagai suatu penciri atau pembeda antar bangsa sapi PO, belgian blue, dan silangan PO-belgian blue.
\end{abstract}

Kata-kata kunci: analisis komponen utama (AKU), sifat kualitatif, sapi silangan

\begin{abstract}
The purpose of this study was to determine the diversity of qualitative traits in PO, belgian blue, and PObelgian blue crosses using principal component analysis. The total samples of cattle used were 36 consisting of 8 heads belgian blue ( 4 males and 4 females), 17 heads belgian PO-belgian cross-breed (11 males and 6 females) and 11 PO heads (all females)). The diversity of qualitative traits observed were 17 characteristics namely plain body-color (WTP), combination body-color (WTK), horned (MT), humped (MP), sagging (MG), black tail tip color (WUEH), white tail tip color (WUEH), black eyelash color (WBMH), white eyelash color (WBMP), circle hair head (PRK), circle hair back (PRP), circle hair bracket (PRB), black nail color (WKH), nail color white (WKP), double muscle (PG), black muzzle (WMH) and white muzzle (WMP). Qualitative data were analyzed descriptively by calculating the proportion value, while the determinant variables of each breeds were analyzed using the principal component analysis method with the Minitab version 7 program. The results showed that the characteristics of qualitative traits in $\mathrm{PO}$, belgian blue, and PO-belgian blue cross-breed cattle
\end{abstract}


have a high diversity. $\mathrm{PO}$ and belgian blue cattle breeds can be clearly distinguished based on the characteristics of qualitative traits, whereas PO-belgian blue crossbred cattle have clusters that are close to PO cattle clusters. Found character traits for each cattle breed in both PO, belgian blue, and PO-belgian blue cross-breed. There are three characteristics of qualitative traits possessed in each cow nation, namely the variable circle hair head (PRK), circle hair back (PRP) and horned characters (MT). Based on the results obtained that the qualitative traits in cattle can be used as a distinguishing character between PO, belgian blue, and PO-blue belgian cross cattle breeds.

Keywords: cross-breeding, principal component analysis (PCA), qualitative traits

\section{PENDAHULUAN}

Sapi peranakan ongole (PO) merupakan salah satu sapi lokal Indonesia yang telah lama berkembang di Indonesia dan merupakan hasil hibridisasi antara sapi bali (Bos javanicus) sapi sumba ongole (SO) yang dikenal sebagai sapi Nellore yang berasal dari India (Hartati et al., 2015). Upaya peningkatan produktivitas sapi PO telah dilakukan melalui program persilangan dengan sapi Simmental dan Limousin sehingga dikenal dengan istilah SimPO dan LimPO (Trifena et al., 2016), akan tetapi program persilangan tersebut tidak berjalan dengan baik dan hasil persilangannya belum didokumentasi-kan dengan baik, sehingga SimPO dan LimPO belum dijadikan sebagai salah satu bangsa sapi pedaging yang secara luas dikembangkan.

Pada tahun 2018, Indonesia melalui Kementrian Pertanian telah memasukkan embrio dan semen sapi belgian blue dari Belgia dan untuk pemanfaatan sumber daya genetik sapi tersebut maka dilakukan transfer embrio dan program persilangan (cross breeding) terutama dengan sapi PO sebagai sapi lokal Indonesia yang bertujuan untuk meningkatkan produktivitas sapi PO. Melalui program persilangan antar bangsa sapi (crossbreeding) terutama sapi PO-belgian blue diharapkan dapat memberikan pengaruh heterosis dan kombinasi gen-gen yang menguntungkan dari setiap bangsa sapi yang disilangkan untuk menghasilkan bangsa baru atau untuk tujuan komersial. Salah satu metode persilangan yang dapat digunakan untuk memperoleh heterosis yang tinggi yaitu persilangan akhir (terminal crossing) dua bangsa atau tiga bangsa (Theunissen et al., 2013). Terdapat beberapa pengaruh positif program persilangan (crossbreeding), dari segi genetik yaitu meningkatkan gen-gen yang heterosigot dan menurunkan gen-gen yang homosigot, sedangkan dari segi fenotipe pengaruhnya adalah meningkatkan produktivitas, nenurunkan abnormalitas, dan kematian (sifat letal) (Bourdon, 2000; Kirkpatrick, 2017). Selain itu, karakteristik morfologi hasil silangan PO-Belgian
Blue merupakan salah satu karakter penting untuk diamati sebagai hasil kombinasi dari dua bangsa sapi berbeda antara PO-belgian blue. Edouard et al. (2018) menyatakan bahwa informasi tentang karakteristik morfologi merupakan salah satu syarat awal untuk peningkatan, pemanfaatan, dan mempertahan-kan suatu bangsa sapi secara berkelanjutan.

Kajian karakteristik morfologi eksternal pada ternak telah intensif dilakukan seperti pada ayam (Assefa \& Melesse, 2018), kambing (Arandas et al., 2017), domba (N'Goran et al., 2019), sapi (Verma et al., 2015; Grema et al., 2017; Dauda et al., 2018) termasuk sapi lokal Indonesia yaitu sapi pasundan (Said et al. 2017) dan sapi madura (Lutvaniyah et al., 2017). Berdasarkan informasi tesebut, karakteristik morfologi eksternal pada sapi PO, belgian blue dan silangannya belum pernah dilaporkan. Oleh karena itu, tujuan penelitian ini adalah menganalisis keragaman morfologi terutama sifat kualitatif pada sapi PO, belgian blue, dan silangan PO-belgian blue menggunakan analisis komponen utama (AKU).

\section{MATERI DAN METODE}

\section{Materi Penelitian}

Penelitian ini menggunakan tiga bangsa sapi yaitu bangsa sapi PO, belgian blue, dan silangan generasi pertama $\left(\mathrm{G}_{1}\right)$ sapi PO dan belgian blue yang dikembangkan di Balai Embrio Ternak (BET) Cipelang Bogor. Total sampel sapi yang digunakan sebanyak 34 ekor terdiri atas sapi PO 11 ekor (semua betina), sapi belgian blue murni 8 ekor (4 ekor jantan dan 4 ekor betina) dan sapi silangan PObelgian blue $\left(\mathrm{G}_{1}\right) 17$ ekor (11 ekor jantan dan 6 ekor betina).

\section{Peubah yang Diamati}

Karakteristik sifat kualitatif yang diamati pada ke tiga bangsa sapi yaitu bangsa sapi PO, belgian blue dan silangan PO-belgian blue $\left(\mathrm{G}_{1}\right)$ diamati secara langsung menggunakan form checklist ada tidaknya karakter (Tabel 1). 
Tabel 1. Karakteristik sifat kualitatif yang diamati

\begin{tabular}{cllc}
\hline No. & Sifat & Karakter & Singkatan \\
\hline 1. & Warna rambut & Polos & WTP \\
2. & Ada tidaknya tanduk & Kombinasi & WTK \\
& & Bertanduk & TT \\
3. & Ada tidaknya punuk & Tidak bertanduk & MP \\
& & Berpunuk & TP \\
4. & Ada tidaknya gelambir & Tidak berpunuk & MG \\
5. & Warna rambut ujung ekor & Bergelambir & TG \\
6. & Warna rambut disekitar mata & Tidak bergelambir & WUEH \\
& & Hitam & WUEP \\
7. & Pusaran rambut & Putih & WBMH \\
& & Hitam & WBMP \\
8. & Warna kuku & Putih & PRK \\
9. & Perototan & Kepala & PRP \\
10. & Warna moncong & Punggung & PRB \\
& & Belakang & WKH \\
\hline
\end{tabular}

\section{Analisis Data}

Data sifat kualitatif sebanyak 17 karakter yang diperoleh dari tiga bangsa sapi ditabulasi dan dianalisis secara deskriptif menggunakan Program Exel 2010 untuk mendapatkan data frekuensi (proporsi dalam \%). Selain itu, untuk mendapatkan cluster dan penentuan peubah penentu pada setiap bangsa dilakukan analisis komponen utama (AKU) atau principle component analysis (PCA) menggunakan program Minitab versi 7.

\section{HASIL DAN PEMBAHASAN}

\section{Karakteristik Sifat Kualitatif}

Hasil analisis sifat kualitatif pada bangsa sapi PO, Belgian Blue dan Silangan PO-Belgian Blue disajikan pada Tabel 2. Tabel 2 menunjukkan bahwa bangsa sapi murni terutama sapi PO dan belgian blue memiliki kakrakteristik yang relatif seragam dibandingkan dengan bangsa sapi silangan PObelgian blue kecuali warna muncung dan warna rambut disekitar mata seragam untuk sapi Silangan. Selain itu, sapi silangan memiliki gelambir sama seperti pada sapi PO, sebaliknya pada sapi belgian blue memiliki otot ganda yang tidak dimiliki oleh sapi PO dan sapi silangan. Berbeda dengan sapi Pasundan yang menunjukkan bahwa karakteristik sifat kualitatif terutama ada tidaknya tanduk dan ada tidaknya punuk menunjukkan keragaman tinggi (Said et al., 2017). Hal ini juga ditemukan pada sapi
Madura baik sapi madura tipe sonok dan pedaging menunjukkan variasi atau keragaman pada karakteristik sifat kualitatif(Lutvaniyah et al., 2017).

Secara umum, ditemukan 11 karakter yang memiliki keragaman sifat kualitatif pada sapi Silangan PO-belgian blue terutama karakter warna tubuh polos (WTP), warna tubuh kombinasi (WTK), memiliki tanduk (MT), memiliki punuk (MP), warna ujung ekor hitam (WUEH), warna ujung ekor putih (WUEP), pusaran rambut dikepala (PRK), pusaran rambut dipunggung (PRP), pusaran rambut dibelakang (PRB), warna kuku hitam (WKH) dan warna kuku putih (WKP), sedangkan 6 karakter bersifat monomorfik atau seragam yaitu memiliki gelambir (MG), warna bulu mata hitam (WBMH), warna bulu mata putih (WBMP), perototan ganda (PG), warna moncong hitam (WHM) dan warna moncong putih (WMP).

Keragaman sifat kualitatif pada sapi silangan PO-belgian blue adalah sebagai kombinasi interaksi gen dari kedua bangsa sapi yang disilangkan yaitu sapi PO dan belgian blue. Karakteristik keragaman sifat kualitatif yang diperoleh terutama dari hasil silangan PO-belgian blue sangat penting sebagai data dasar dalam pengembangan ke depan sebagaimana dinyatakan oleh Edouard et al. (2018) bahwa karakteristik morfologi dapat digunakan dalam upaya meningkatkan, memanfaatkan, dan mempertahankan suatu bangsa sapi secara berkelanjutan. 
Tabel 2. Proporsi (\%) sifat kualitatif pada bangsa sapi yang dianalisis

\begin{tabular}{lcccccc}
\hline \multirow{2}{*}{ Karakter } & \multicolumn{7}{c}{ Bangsa } \\
\cline { 2 - 7 } & \multicolumn{2}{c}{ Belgian Blue $(\mathrm{n}=8)$} & \multicolumn{2}{c}{ Silangan BB-PO $(\mathrm{n}=17)$} & \multicolumn{2}{c}{ PO (n=11) } \\
\cline { 2 - 7 } WTP & Ada & Tidak & Ada & Tidak & Ada & Tidak \\
WTK & 0 & 100 & 11.11 & 88.89 & 90 & 10 \\
MT & 100 & 0 & 88.89 & 11.11 & 10 & 90 \\
MP & 100 & 0 & 66.67 & 33.33 & 70 & 30 \\
MG & 0 & 100 & 77.78 & 22.22 & 100 & 0 \\
WUEH & 0 & 100 & 100 & 0 & 100 & 0 \\
WUEP & 12.5 & 87.5 & 77.78 & 22.22 & 100 & 0 \\
WBMH & 87.5 & 12.5 & 22.22 & 77.78 & 0 & 100 \\
WBMP & 100 & 0 & 100 & 0 & 90 & 10 \\
PRK & 0 & 100 & 0 & 100 & 10 & 90 \\
PRP & 37.5 & 62.5 & 77 & 22.22 & 60 & 40 \\
PRB & 62.5 & 37.5 & 16.67 & 83.33 & 40 & 60 \\
WKH & 0 & 100 & 5.56 & 94.44 & 0 & 100 \\
WKP & 25 & 75 & 94.44 & 5.56 & 100 & 0 \\
PG & 75 & 25 & 5.56 & 94.44 & 0 & 100 \\
WMH & 100 & 0 & 0 & 100 & 0 & 100 \\
WMP & 100 & 0 & 100 & 0 & 100 & 0 \\
\hline & 0 & 100 & 0 & 100 & 0 & 100 \\
\hline
\end{tabular}

\section{Analisis Komponen Utama (AKU)}

Berdasarkan hasil AKU terhadap 17 karakter sifat kualitatif menunjukkan perbedaan yang terbagi dalam dua kelompok besar atau cluster (Gambar 1). Kelompok pertama adalah kelompok bangsa sapi Belgian Blue (hitam) dan kelompok kedua adalah sapi PO (hijua), sedangkan sapi Silangan POBelgian Blue memiliki posisi yang dekat dengan sapi PO (merah). Hasil ini menunjukkan bahwa karakterisik sifat kualitatif dapat membedakan antar bangsa sapi termasuk posisi hasil silangannya. Hasil AKU yang dilakukan terhadap 11 karakteristik sifat kualitatif pada sapi Kuri dan empat bangsa sapi lain yang termasuk dalam Bos taurus Afrika menunjukkan bahwa karakteristik sifat kualitatif dapat dijadikan sebagai tool untuk membuat perbedaan kelompok atau cluster antar bangsa dengan keragaman tinggi (Grema et al. 2017).

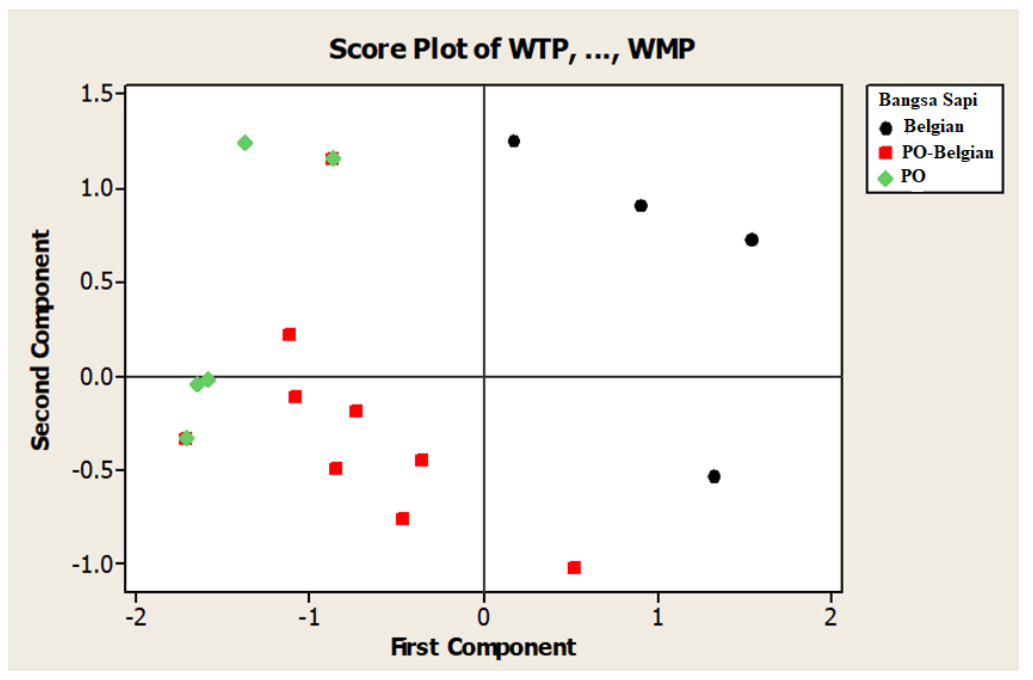

Gambar 1. Hasil AKU berdasarkan perbedaan bangsa 


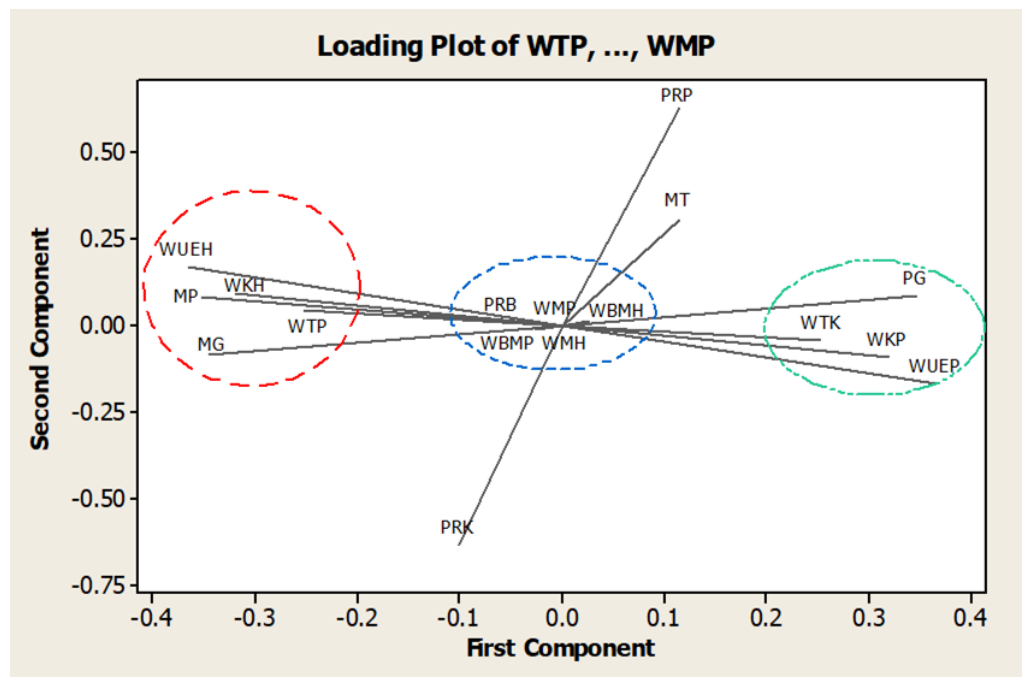

Gambar 2. Hasil analisis AKU berdasarkan karakter.

Tabel 3. Karakter penciri suatu bangsa berdasarkan hasil AKU

\begin{tabular}{|c|c|c|c|c|}
\hline \multirow{2}{*}{ Karakter } & \multirow{2}{*}{ Singkatan } & \multicolumn{3}{|c|}{ Bangsa } \\
\hline & & Belgian Blue & $\mathrm{PO}$ & Silangan \\
\hline Perototan ganda & PG & + & & \\
\hline Warna kuku putih & WKP & + & & \\
\hline Warna tubuh kombinasi & WTK & + & & \\
\hline Warna ujung ekor putih & WUEP & + & & \\
\hline Warna ujung ekor hitam & WEUH & & + & \\
\hline Warna kuku hitam & WKH & & + & \\
\hline Memiliki punuk & MP & & + & \\
\hline Memiliki gelambir & MG & & + & \\
\hline Warna tubuh polos & WTP & & + & \\
\hline Pusaran rambut dibelakang & PRB & & & + \\
\hline Warna moncong hitam & WMH & & & + \\
\hline Warna moncong putih & WMP & & & + \\
\hline Warna bulu mata hitam & WBMH & & & + \\
\hline Warna bulu mata putih & WBMP & & & + \\
\hline
\end{tabular}

Keterangan : + adalah hanya dimiliki

Hasil AKU berdasarkan pada karakter penciri pada setiap bangsa sapi yang dianalisis menunjukkan bahwa terdapat beberapa karakter pembeda yang dapat menjadi penciri suatu bangsa (Gambar 2) (Tabel 3). Terdapat tiga karakter yaitu pusaran rambut dikepala (PRK), pusaran rambut dipunggung (PRP) dan memiliki tanduk (MT) dimiliki oleh setiap bangsa sapi. Berdasarkan hasil yang diperoleh menunjukkan bahwa karakteristik penentu sebagai penciri umum suatu bangsa tenak terutama pada sapi PO sebagai sapi yang termasuk dalam kelompok Bos inidicus adalah memiliki punuk dan bergelambir. Demikian pula dengan sapi Belgian Blue yang memiliki karakter penentu adalah otot ganda (double muscle) dan termasuk dalam kelompok sapi Bos taurus. Dalam perkembangan sejarah domestikasi sapi secara umum dibedakan dalam tiga kategori yaitu sapi yang termasuk dalam Bos taurus, Bos indicus dan
Bos javanicus (MacHugh et al., 1997; Martojo, 2012).

\section{KESIMPULAN}

Karakteristik sifat kualitatatif pada sapi PO dan belgian blue lebih seragam dibandingkan dengan silangan PO-belgian blue pada generasi pertama (G1). Berdasarkan hasil AKU terhadap karakteristik sifat kualitatif diperoleh dua kelompok yang sangat berbeda yang dicerminkan oleh kelompok sapi belgian blue dan PO, sedangkan sapi Silangan PO-belgian blue masuk dalam kelompok sapi PO. Didapatkan karakter penciri pada setiap bangsa sapi PO, belgian blue dan silangan PObelgian blue pada generasi pertama (G1). Namun demikian ditemukan tiga karakter yang dimiliki pada ketiga bangsa sapi yaitu karakter pusaran rambut dikepala (PRK), pusaran rambut dipunggung (PRP), dan memiliki tanduk (MT). 


\section{UCAPAN TERIMA KASIH}

Penelitian ini didanai melalui skema Penelitian Terapan (Strategis Nasional) dengan Nomor 4313/IT3.L1/PN/2019. Terima kasih juga kami sampaikan kepada Kepala Balai Embrio Ternak (BET) Cipelang Bogor atas fasilitasi penelitian yang dilakukan.

\section{DAFTAR PUSTAKA}

Arandas, J.K.G., N.M.V. da Silva, R.B. Nascimento, E.C.P. Filho, L.H. Brasil, \& M.N. Ribeiro. 2017. Multivariate analysis as a tool for phenotypic characterization of an endangered breed. J. Appl. Anim. Res. 45:152-158.

Assefa H. \& A. Melesse. 2018. Morphological and morphometric characterization of indigenous chicken populations in Sheka Zone, South Western Ethiopia. Poultry, Fish. Wildl. Sci. 06:1-9.

Bourdon R.M. 2000. Understanding Animal Breeding. Prentice Hall. Upper Saddle River, New Jersey 07458

Dauda A., M. Anya, A. Ayuk, B. Okon \& P. Eburu. 2018. Application of morphological indices and distribution of qualitative traits of cattle in Obudu grass plateau-cross river state. J. Res. Rep. Genet. 2:5-9.

Edouard N. K., B.K. Lacine, K.N. Cyrille, L.N. Etienne, D. Guiguigbaza-Kossigan, S. Mamadou, \& Y.G.C. Valentine. 2018. Multivariate Analysis for Morphological Characteristics of N'Dama Cattle Breed in Two Agro-ecological Zones of Côte d'Ivoire. Eur. Sci. Journal, ESJ 14:602-621.

Grema M., A. Traoré, M. Issa, M. Hamani, M. Abdou, I. Fernández, A. Soudré, I. Álvarez, M. Sanou, H.H. Tamboura, Y. Alhassane, \& F. Goyache, 2017. Morphological assessment of Niger Kuri cattle using multivariate methods. South African J. Anim. Sci. 47:505-515.

Hartati H., Y.T. Utsunomiya, T.S. Sonstegard, J.F. Garcia, J. Jakaria \& M. Muladno. 2015. Evidence of Bos javanicus x Bos indicus hybridization and major QTLs for birth weight in Indonesian Peranakan Ongole cattle. BMC Genet. 16:1-9.

Kirkpatrick F. D. 2017. Crossbreeding in Beef Cattle. Department of Animal Science. University of Tennessee Institute of Agriculture. U.S.

Lutvaniyah S., D.P. Farajallah \& A. Farajallah. 2017. Morphological characters comparison of sonok and madura cattle. J. Ilmu Pertan. Indones. 22:67-72.

MacHugh D. E., M.D. Shriver, R.T. Loftus, P. Cunningham, \& D.G. Bradley. 1997. Microsatellite DNA variation and the evolution, domestication and phylogeography of taurine and zebu cattle (Bos taurus and Bos indicus). Genetics 146:1071-1086.

Martojo H. 2012. Indigenous bali cattle is most suitable for sustainable small farming in Indonesia. Reprod. Domest. Anim. 47:10-14.

N'Goran K. E., G.S. Kouadja, N.C. Kouassi, N.E. Loukou, J.Y. Eka, G.K.C. Dayo, M. Sangare, \& C.V. Yapi-Gnaore. 2019. Primary morphological characterization of West African dwarf (Djallonk) ewes from Cte dIvoire based on qualitative and quantitative traits. Int. J. Genet. Mol. Biol. 11:16-28.

Said S., W.B. Putra, S. Anwar, P.P. Agung, \& H. Yuhani. 2017. Phenotypic, morphometric characterization and population structure of Pasundan cattle at West Java, Indonesia. Biodiversitas 18:1638-1645.

Theunissen A., M.M. Scholtz, F.W.C. Neser, \& M.D. MacNeil. 2013. Crossbreeding to increase beef production: additive and nonadditive effects on weight traits. S. Afr. J. Anim. Sci. 43:143-151.

Trifena T., I.G.S. Budisatria, \& T. Hartatik. 2016. The phenotypic chages of first fillial and backcross of ongole grade, simpo and limpo cows. Bul. Peternak 35:11-16.

Verma D., V. Sankhyan, S. Katoch, \& Y.P. Thakur 2015. Principal component analysis of biometric traits to reveal body confirmation in local hill cattle of Himalayan state of Himachal Pradesh, India. Vet. World 8:1453-1457. 